\title{
Online Education as Institutional Myth: Rituals and Realities at Community Colleges
}

\author{
REBECCA D. COX \\ Community College Research Center, Teachers College
}

Relying on data from an in-depth study of 15 community colleges, this article explores online education through the lens of institutional theory. This theoretical perspective highlights the colleges' environmental contexts and offers a critical examination of the ways that the institutional contexts have structured the colleges' approaches to online education. At the core of this analysis is the contention that community colleges are interpreting and responding to a set of taken-for-granted ideas about online education. These ideas have taken on the status of myth and have played a powerful role in guiding and legitimating colleges' online activity. This analysis provides a research-based foundation for understanding online activity at the community college level and for carefully addressing the challenges associated with its adoption.

Online education has become a central component of the discourse on higher education. This newest form of distance education is accompanied by a rich metaphoric language, with terms such as "open education" and "e-learning." These descriptors hint at the educational promise of the new digital technologies: open access to higher education, the development of students' digital literacy skills, and a more engaging learning experience. ${ }^{1}$ Advocates have touted online education as a means of "delivering" instruction to a wide range of lifelong learners, "anywhere, anytime," and hail it as the harbinger of a complete transformation in teaching, learning, and formal schooling.

In contrast, critics foresee dire consequences for faculty and students and predict a future for higher education that is marked by increasing social stratification and inequality. Historian David Noble (1998), for example, outlines the history of correspondence courses, arguing that the use of newer technologies does not inherently distinguish online education from prior-and now discredited - versions of distance education. Noble concludes by describing "the digital diploma mills now in the making": 
Quality higher education will not disappear entirely, but it will soon become the exclusive preserve of the privileged, available only to children of the rich and the powerful. For the rest of us a dismal new era of higher education has dawned. In ten years, we will look upon the wired remains of our once great democratic higher education systems and wonder how we let it happen. That is, unless we decide now not to let it happen. (p. 10)

These prognoses - whether wildly optimistic or gloomy-share a key premise: Online technologies are playing an important role in reconfiguring the postsecondary landscape. Even the more cautious observers contend that higher education is undergoing transformation (Erhmann, 1999; Newman, 2000). In their attempt to locate the middle ground, Burbules and Callister (2000) avow:

There really is no choice for colleges and universities. Where these technologies are widely available, where the cost and convenience factors are of such potential importance, and where the demand is increasing, someone will step into the vacuum if colleges and universities do not. ... In such a competitive context, there may be a few schools with sufficient prestige not to worry that they will lose students to other providers. But for the vast majority ... the race is on. (pp. 278-279)

This vivid rhetoric, however, has eclipsed the empirical data. If "the race is on," who are participating? And how are they faring?

Within the field of higher education, the community college sector represents a crucial site for investigating online education and understanding the implications of colleges' online involvement. Not only do community colleges enroll the majority of postsecondary students, but they also play a major role in providing distance education through a range of media (Council for Higher Education Accreditation, 2000; National Center for Education Statistics, 2002). In addition to older media, such as live or prerecorded telecourses, phone conferencing, radio broadcasting, and audiotapes, the use of newer digital technology ranges from interactive video conferencing and multimedia CD-ROMs to Web-based instruction. Webbased technology consists of "real-time" (synchronous) computer conferencing or, more commonly, asynchronous instruction that employs e-mail, listservs and/or threaded discussion groups. ${ }^{2}$

Thus, in terms of the sheer number of distance education students, community colleges offer a strategic site of study. At the same time, the extent and nature of community college involvement in Web-based distance education is not entirely clear, and the need for empirical research is par- 
ticularly acute. To date, much of the literature on online education-both empirical and theoretical-has addressed the concerns and contexts of 4 -year colleges and universities and remained relatively silent about community colleges (e.g., K. A. Meyer, 2002; Palattella, 2001; Trow, 2000; Twigg, 2002).

And finally, while an analysis of online education is relevant to the entire field of higher education, it is critically important for the community college sector, which enables access to higher education for the least-advantaged students. Providing postsecondary education for working-class and minority students (Cohen \& Brawer, 1996), midskilled workers (Grubb, 1996), and those in need of postsecondary remediation (Spann, 2000), community colleges lack the resources and status garnered by other postsecondary institutions.

Therefore, as community colleges respond to the demands of the educational market, their capacity to provide authentic educational and economic opportunities deserves sustained attention. Market forces do not operate on the principle of equitable distribution or equitable outcomes. And as Frank Newman (2000) observes, there is an immense difference between fulfilling market demand, catering to "easy-to-educate students who have the resources to pay," and fulfilling a public need, providing high quality instruction for "students who are poor and harder to educate" (p. 21). For the community college sector, which enables access to higher education for the least-advantaged students, clarifying the current state of online practice is essential to preserving the democratizing aspects of public postsecondary schooling.

Understanding the implications of Web-based education requires a detailed description of current structures, conditions, and practices. In an effort to document community colleges' involvement with newer, computerbased technologies and to understand the implications of that involvement, the Community College Research Center (CCRC) at Teachers College recently conducted a national field study of community colleges and incorporated online education as a key topic of investigation.

The purpose of this article is to explore the data from the CCRC study through the lens of institutional theory. This perspective highlights the colleges' environmental contexts and offers a critical examination of the ways that the institutional contexts have structured these colleges' approaches to online education. At the core of the analysis is the contention that community college actors are interpreting and responding to a set of taken-for-granted ideas about online education. These ideas have taken on the status of myth and have played a powerful role in guiding and legitimating colleges' online activity.

Following the methodological discussion is an overview of findings from the study. The data reveal an intriguing pattern that makes most sense 
when seen through lens of institutional theory. Following the overview of findings is an outline of the theoretical framework and an exploration of online education as an institutional myth, including examples of organizational responses to the myth. Last is a brief discussion of the implications for the community college sector. This analysis provides a research-based foundation for understanding online activity at the community college level and for carefully addressing the challenges associated with its adoption.

\section{DATA AND METHODS}

This article relies on data from the CCRC's national field study, a large-scale investigation of 15 community colleges across six states. Designed as a comparison case study (Yin, 1989), the project explored changes in the community college landscape, particularly those effected by state-led accountability demands, the rising demand for remediation, the emergence of new postsecondary competitors, and recent developments in Web-based technologies. ${ }^{3}$ Each of the six states (California, Washington, Florida, New York, Illinois, and Texas) maintains a well-elaborated system of community colleges as part of its commitment to public higher education, and together, these states account for over one third of the public community colleges in the United States. The 15 community colleges investigated include urban, suburban, and rural colleges. The research questions for the online education strand of investigation included:

- What are the specific conditions shaping community colleges' approaches to online education?

- How are different community colleges responding to the challenges of creating online programs?

\section{DATA COLLECTION}

Data were gathered over 2 years (2000-2002). After determining each college's organizational structure from documents and phone calls, a team of three to five researchers visited the site and conducted interviews with a systematically selected set of administrators, faculty, and students (Table 1). Across all 15 colleges, the interview respondents consisted of 284 administrators, 278 faculty members, and 68 students.

At each college, at least two interviews were dedicated solely to the topic of online education: an individual interview with the person most directly responsible for the online program and a group interview with faculty members involved in online teaching. These interviews provided detailed 
Table 1. Interview respondents

\begin{tabular}{ll}
\hline College president & Senior administrators \\
District-level chancellor (if applicable) & Academic instruction \\
Academic advisors & Occupational programs \\
Career counselors & Finance \\
Program directors & Student services \\
Distance/online education & Faculty members \\
Institutional research & Faculty senate president \\
General education & Adjunct faculty president \\
Workforce development & Union representative \\
Continuing/adult education & Several online faculty \\
Counseling & Basic skills instructors \\
Dual-enrollment programs & Math instructors \\
Contract/customized training & English instructors \\
Enrollment/admissions services & Department chairs \\
Budgeting & Additional instructors of academic \\
Basic skills program & and occupational courses \\
\hline
\end{tabular}

Note. The number of participants at each college depended on the college's size and organizational structure; at smaller colleges, each administrator took on roles that at a larger college would be distributed among several administrative positions.

information about the organization of the program, the resources available to online students, the process of course development, opportunities for faculty development, classroom-level curricula and practices, and strategies for assessing course and program quality. To validate interview responses about the organizational and support structures for online education, we gathered a range of documents, including (a) internal research reports and quantitative program data (when available), (b) online training materials for faculty, and (c) information targeted at online students, including print-based documents and Web-based data. Additionally, in order to capture a full range of perspectives across the college, questions about the college's online education program were incorporated into all of the interview protocols. These questions explored respondents' perspectives on the history and scope of the college's online involvement, the impetus for that involvement, and the value of offering online courses. Typically, particular administrators offered substantial comments on the topic, including vice presidents of academic instruction, finance and student services, as well as the heads of enrollment services and institutional research. Similarly, discussions about online education occurred with many faculty who were not participating in online courses. Various faculty representatives - for full-time instructors, adjuncts, and union members at each college-were also consistent contributors to the investigation of online education. 


\section{DATA ANALYSIS}

For each college, an interim case summary was written using the researchers' field notes and documents gathered during the site visit (Miles \& Huberman, 1994). Once interviews were transcribed and coded according to research topics, all of the data were ordered by case, contributing to a robust understanding of each college. At several points during the data collection phase, the entire research team formally convened to review analytic memos. This collaborative process generated constructive feedback on analytic claims and the evidentiary warrant. These case summaries anchored my cross-case analysis of online education.

To analyze the data specific to the online topic, I used the set of onlinerelated documents gathered from each college to assemble an objective account of the online program's organizational features. I also focused on a subset of interviews with administrators and faculty. To select this subsample, I reviewed interview transcripts of approximately $80 \%$ of the respondents across all 15 colleges. ${ }^{4}$ Of the transcripts I read, slightly fewer than $50 \%$ contained explicit references to online education. I used this subsample $(n=210$ respondents) to understand the experiences and perspectives of respondents across each college, thereby building on the individual case studies. My analytic approach entailed developing a more refined set of thematic codes for the interview data and creating a detailed matrix for each college's involvement with online education. In addition, a pattern of responses emerged across three key constituent groups - senior administrators, program directors and faculty members - so I also analyzed these data by group membership. Ultimately this approach revealed patterns of online development across colleges, details of online involvement within each college, and distinct discourses and attitudes around online expansion; it also allowed me to situate each college's online involvement within the college's organizational and environmental contexts.

\section{OVERVIEW OF FINDINGS}

The process of establishing and expanding an online program generally starts with a few faculty members-most likely technologically inclined - who are inspired (or requested) to experiment with online-course development. These faculty members typically share the characteristics of the "innovators" or "early adopters" described in the innovation literature (Rogers, 1962). ${ }^{5}$

The organizational and technological complications of supporting initial online courses are vexing; accommodating even a small number of online students requires an immense investment in technology, technology sup- 
port, and student support services. Once those basic structures and services are established, encouraging greater faculty participation requires administrators to appeal to a new audience of faculty, who differ significantly from the early innovators. More skeptical of online courses' alleged advantages, they demand greater levels of organizational support while preparing to teach and while teaching online. Thus, successful expansion into a coherent program requires an administrative commitment to coordinating the necessary structures and encouraging more faculty to teach online.

\section{COLLEGES' ONLINE INVOLVEMENT}

For the colleges in our sample, the extent of online offerings corresponded to the college's capacity to assemble and coordinate six basic components (Figure 1). The fundamental component is, of course, the technological infrastructure. At these colleges, infrastructure consisted of relatively up-todate computers for online faculty and access to an online course management system (e.g., Blackboard). In five states, the colleges' access to such a system could be coordinated through a state- or regional-level consortium of colleges. The existence of the basic infrastructure did not necessarily mean that a college had put student services online. The availability of student services, therefore, constituted a distinct component of basic online capacity. This involved making services such as course registration, advising, and access to library materials available to distance students (although again, not necessarily through Web-based media). Administrative commit-

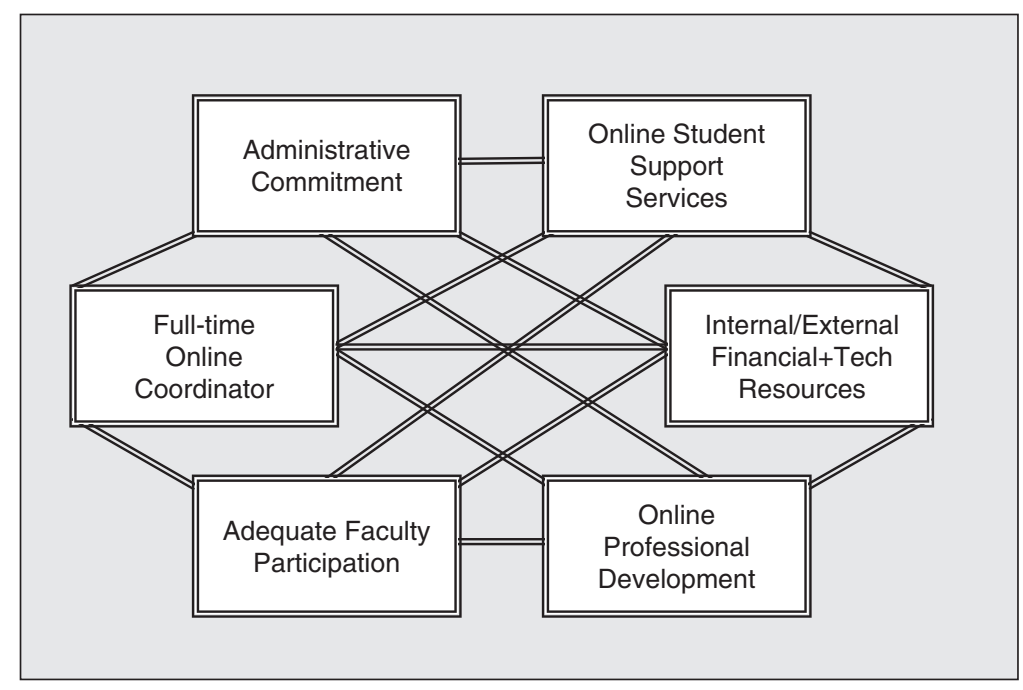

Figure 1. Components of Basic Online Capacity 
ment required the support of at least one senior administrator who maintains the authority to allocate (or redistribute) resources. A full-time online coordinator spent a majority of time on curricular and programmatic issues, as opposed to technology support issues. A basic level of professional development involved targeting resources at the college level to assist instructors with course development and online teaching issues. Underlying these faculty resources was a planned approach to developing instructors' online knowledge. Finally, basic online capacity required an adequate level of faculty participation. The study did not suggest a minimum number of participants needed for "adequate" faculty involvement, but the condition of inadequate faculty participation was quite clear: few online innovators (fewer than four) among a faculty whose representatives voiced strong criticism of the college's approach to online education. ${ }^{6}$

At the time of our site visits, 5 of the 15 colleges in the sample maintained all six components of basic online capacity. All large, urban colleges, they offered their first online courses in the mid-1990s. Administrative commitment had emerged in the early 1990s, at which point senior-level leadership had enacted decisive measures to build the college's technological infrastructure. The college's ability to make such an investment was facilitated by its preexisting capacity to attract industry support and to take advantage of emergent community partnerships. Additionally, the size of these colleges has helped to ensure an adequate number of online innovators among the college's faculty.

Despite the stability of these five online programs, issues of faculty compensation, intellectual property, and course evaluation remained unresolved. Moreover, online coordinators at these sites spoke of their plans to examine and improve the quality of the program. Thus, at the high end of online expansion, colleges had established the basic structural components but were only beginning to address more substantive instructional concerns. Even more surprising was the minimal level of functioning for some of the program components. For example, one college still conducted course registration in person. Although the coordinators could make exceptions for distance students when absolutely necessary, standard policies did not allow phone registration, much less online registration. At another college, the online coordinator confessed that although online students could receive academic counseling by phone, the advisors were not well informed about the online program and therefore often dispensed misleading advice.

At the low end of online involvement were three colleges with minimal capacity to offer online courses (see Table 2). Located in three different states, these colleges (two urban and one rural) were very poorly positioned to afford the cost of establishing a program. Each was able to offer a few online courses but was unable to assemble any components other than the 
Table 2. Colleges' online development

\begin{tabular}{|c|c|c|c|c|c|}
\hline \multirow{2}{*}{$\frac{\text { College }^{\mathrm{a}}}{\mathrm{CU}}$} & \multicolumn{2}{|c|}{ Geography } & \multirow{2}{*}{$\begin{array}{l}\text { Online capacity } \\
\text { Minimal }\end{array}$} & \multirow{2}{*}{$\begin{array}{c}\begin{array}{c}\text { Year of first online } \\
\text { offerings }\end{array} \\
2000\end{array}$} & \multirow{2}{*}{$\begin{array}{c}\begin{array}{c}\text { Number of } \\
\text { courses } \\
(\text { Fall 2002) }\end{array} \\
3\end{array}$} \\
\hline & CA & Urban & & & \\
\hline CS & CA & Suburban & In progress & n.a. & 10 \\
\hline CR & CA & Rural & In progress & 1998 & 26 \\
\hline FMR & FL & Mixed $^{\mathrm{b}}$ & In progress & 1997 & 78 \\
\hline FMU & FL & Mixed $^{\mathrm{b}}$ & Basic capacity & 1996 & 57 \\
\hline IU & IL & Urban & Basic capacity & 1995 & 30 \\
\hline IR & IL & Rural & In progress & 1998 & 20 \\
\hline IS & IL & Suburban & In progress & 1997 & 56 \\
\hline $\mathrm{NU}$ & NY & Urban & Minimal & n.a. & 2 \\
\hline NR & NY & Rural & In progress & 1997 & 20 \\
\hline NS & NY & Suburban & Basic capacity & 1997 & 70 \\
\hline TU & TX & Urban & Basic capacity & 1994 & 65 \\
\hline $\mathrm{TS}$ & $\mathrm{TX}$ & Suburban & In progress & 1997 & 58 \\
\hline WU & WA & Urban & Basic capacity & 1996 & 110 \\
\hline WR & WA & Rural & Minimal & 1998 & 20 \\
\hline
\end{tabular}

Note. n.a. = data not available.

aThese abbreviations have been assigned to maintain the colleges' anonymity. The labels locate them geographically. For example, CU, CS, CR are the three colleges in California - one urban, one suburban, one rural.

${ }^{\mathrm{b}}$ Mixed geography refers to a service district that encompasses both urban and rural regions.

basic infrastructure. Not coincidentally, these colleges served particularly disadvantaged student populations.

The remaining seven colleges were still working to reach the point of relative stability. The variation among these colleges' online efforts illustrated the importance of the local conditions affecting each college's operation. In short, the crucial local factors included the college's financial status and the dominant administrative perspective of the college's mission relative to its competitors. These local conditions proved more influential than online policies implemented at the state level. For instance, one state had decided to reimburse colleges' online enrollments at a lower rate than that for on-site students. The colleges located in this state, however, viewed the economics of offering online courses very differently. At the first college, CS (suburban), ${ }^{7}$ an initial cost analysis led to the decision not to pursue online development. During our visit, the administrators cited their reputation as a "learning" college as the rationale for eschewing online development. Instead, they preferred to promote innovations aimed at improving the quality of teaching and learning. In contrast, the president of the second college (CR, rural) had committed to a speedy expansion of an online program. To compensate for the state funding differential between online and 
on-site courses, he increased the size of online courses, establishing an enrollment maximum of 60 students, in comparison to the 30 -student limit of most on-site courses.

Thus, relative to the role of state-level policies in shaping a college's online program, the more powerful influences for the colleges were located at the organizational level, as college-level actors interpreted and responded to the institutional contexts. As a result, the process of assembling and coordinating the basic online components did not reflect one particular developmental chronology. Instead, online expansion has been directed by the conditions and responses at the organizational level. Ultimately, the variation in online involvement among these 15 colleges has provided rich data on the processes of organizational change and the specific contexts for each college's online participation.

\section{THE ONLINE DIVIDE: REPRESENTATIONS VERSUS PRACTICES}

At the same time, a consistent pattern has emerged across all of the colleges, regardless of the status of the online program or the specific conditions composing the college's local environment. At a fundamental level, every online program has manifested a significant disconnect, which separates the curricular and programmatic details of the college's actual online practice from representations of the online program. As a rule, this disconnect manifested itself in a jarring contrast between the rhetoric of online education among college administrators and the depth of the program's structural components.

The disconnect also emerged as a significant contrast between senior administrators' views and faculty perspectives. While the vast majority of senior administrators interviewed at each college expressed a consensus about the value and purposes of online education, faculty respondents offered a variety of assertions about the impetus for and consequences of its development. The consensus among the majority of administrators reflected two assumptions: The community college must offer online education to maintain its competitiveness, and the advantage of online education is that it increases the community college's accessibility. For faculty respondents, however, online education was a highly contested area of college activity, and the experiences of online faculty participants at each college challenged the dominant perspective of colleges' administrators.

Two colleges emerged as partial exceptions to this pattern of administrator exuberance. In each instance, senior administrators articulated substantial reservations about online courses in regard to students' learning outcomes. At both colleges, respondents consistently described the college as strongly committed to core issues of teaching and learning. In addition, each enjoyed that reputation beyond the walls of the college; in both cases they participated in cross-college initiatives focused on supporting teaching 
and learning innovations. In this respect, an organizational saga had emerged at each college, embodying the college's distinctive identity and providing strong justification at the organizational level for pursuing activities that might further differentiate it from other community colleges (Clark, 1970). At one college (CS), still in the process of assembling the components of an online program, the majority of administrators shared a uniform vision of online education, noting that the college did not really "do" any distance education. However, this contention did not prove to be accurate. ${ }^{9}$ Although the college was not actively working to build an online program, it did offer a range of online courses, some of which were part of a well-established program in allied health. As a result, despite the absence of an online coordinator and online professional development, a number of instructors engaged independently in online innovations. Thus, despite the difference in administrator rhetoric-dominantly skeptical rather than exuberant - the college maintained the same fundamental breach between the online rhetoric and the practical realities.

At the other self-described "learning college" (FMU), the online program exhibited all components of basic capacity, offered over 50 courses, and was continuing to expand its offerings. At the same time, the president expressed her plans to reshape the program and focus on hybrid courses, which meet online for only $50 \%$ of the time. In fact, this college was atypical, in that the administrators had sought out and read recent research findings on online education. Likewise, the online program had undergone a formal evaluation, an activity that had been undertaken at only one other college in the sample. However, despite the president's research-based contention that hybrid courses are more appropriate for a college concerned with students' learning, the momentum of the college's online expansion made it unlikely that a dramatic restructuring would occur anytime soon. Fundamentally, neither college's organizational saga accounted for online education's emergence and expansion inside the college.

\section{ACCOUNTING FOR THE ONLINE DIVIDE}

The explanation for this persistent and pervasive disconnect between representation and practice lies in the web of institutional contexts that guide community college activity. Indeed, the insights from institutional theory, particularly those associated with the "new" institutionalism (DiMaggio \& Powell, 1991a), offer a coherent framework for understanding the patterns of online practices emerging across these colleges. In response to pressures from the external environment, community colleges have felt compelled to adopt online education. Colleges' decision to provide online education has been guided by a particular vision of online education, and although this vision has arisen from unsubstantiated beliefs, it maintains the authority of 
fact-based truth. In this way, online education has taken on the status of myth (J. W. Meyer \& Rowan, 1977) within the field of higher education.

Examining the myth and its effects through the lens of institutional theory clarifies several critical aspects of colleges' online involvement. First, it explains the emergence of the myth and the source of its authority in the field of higher education. Second, it explains why community colleges have adopted online education. Third, and most importantly, by locating community colleges within a multilayered institutional context, it highlights the organizational advantages of maintaining the disconnect between online representations and online practices.

\section{OVERVIEW OF INSTITUTIONAL THEORY}

In general, institutional theory provides a useful lens for understanding how organizations respond to the conditions of their environment. At the base of the theoretical framework is the conception of the environment as a set of institutional rules that guide and legitimate the work of organizations. For the following analysis of community college data, the crucial institutional contexts include the sociopolitical system, the American educational system, the field of higher education, and the community college sector (Figure 2). Community college organizing is therefore shaped by multiple

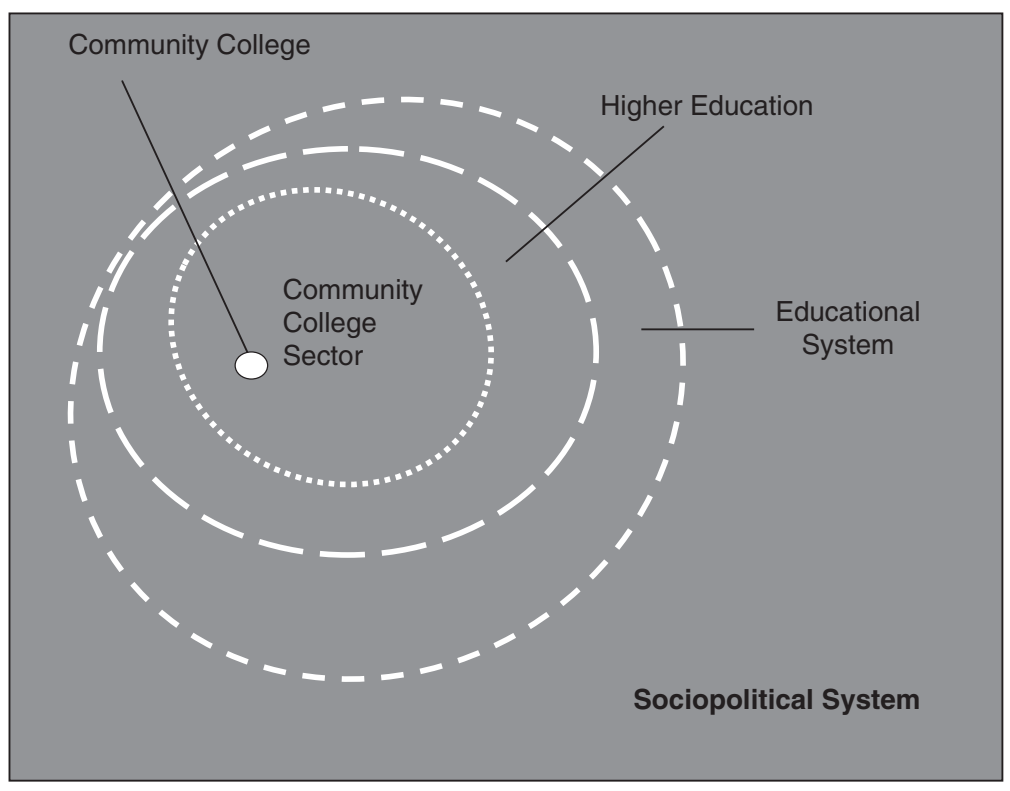

Figure 2. Institutional Fields 
institutional rules, embedded and variously enacted in each institutional sphere (Scott, 1991; Zucker, 1987).

Functioning as the most fundamental institutional context is the American sociopolitical system, which comprises the state, the spheres of public discourse, and civil society (Jepperson \& Meyer, 1991). ${ }^{10}$ This macro-level system both sets the stage for and defines the objectives of a wide range of organizing efforts that purport to advance the public good. Thus, the very landscape of an organizational field, such as higher education, is structured by sociopolitical definitions of its purpose and appropriate forms. In the case of American higher education, the commonsense understanding of its purpose incorporates three fundamental axioms. They posit direct links between (a) the nation's economic health and the condition of higher education, (b) access to higher education and the strength of civil society, and (c) an individual's economic success and his postsecondary educational credentials. ${ }^{11}$ Thus, higher education is defined as a mechanism for ensuring a well-functioning capitalist economy and democratic state. In addition, these assumptions unite individuals' private interests with the good of the system. These definitions shape the activities and identities constituted in postsecondary organizations in ways that reproduce the legitimacy of the larger sociopolitical system.

The socially constructed nature of these assumptions, however, is obscured, rendered invisible by their natural and commonsense appearance (Berger \& Luckmann, 1967; Garfinkel, 1967; Zucker, 1987). Thus, social goals are perceived as "objective, technical rules/facts" (J. W. Meyer \& Rowan, 1977, pp. 343-344). The source of these "facts" is not the objective practice of higher education, but rather a set of normative myths. Indeed, in practice, these three educational purposes are not compatible, in large part because the economy can accommodate only a limited number of highskilled, professional workers.

The community college serves a crucial role in addressing the competing claims of higher education. It provides a well-articulated path up the postsecondary educational ladder, offering the promise of upward mobility to the meritorious while supporting a highly stratified system of education. Through its open-access admissions policy, the community college offers this opportunity to the entire citizenry, and yet it more often serves to prepare students to work in midskilled occupational positions, thereby helping to maintain the nation's inequitable economic structure (Brint \& Karabel, 1989). ${ }^{12}$ Its most democratizing feature, the nonselective admissions process, places the community college at the bottom tier of the postsecondary hierarchy. Consequently, the community college is allocated the fewest resources while facing the most difficult teaching demands (Grubb, 1996, p. xvi).

In sum, the institutional rules that structure the community college's organizational form and objectives do not necessarily promote its technical 
work outcomes (J. W. Meyer \& Rowan, 1977). The community college thereby lends credibility to democratic ideals without necessarily effecting democratic outcomes (Dougherty, 1994). It is quite possible, for instance, that ensuring higher levels of educational success for all students would require entirely different organizational forms. However, the community college's legitimacy as a "college" is predicated on its fitting in with the other organizations of higher education. Therefore, community colleges adopt the organizational structures of other, high-status colleges and universities (DiMaggio \& Powell, 1991b). By incorporating such institutionally defined structures and procedures, colleges "increase their legitimacy and their survival prospects, independent of the immediate efficacy of the acquired practices and procedures [italics added]" (J. W. Meyer \& Rowan, p. 340).

The utility of the term "myth" in Meyer and Rowan's classic formulation is that it highlights the socially constructed nature of these rules. Although these institutional rules take on the status of factual information or everyday common sense, what generates these commonly accepted understandings are sociopolitical values, not unequivocal empirical evidence. At the micro level, individuals play a "major role in creating the world toward which they subsequently "respond," " making sense of their environments by reflecting on and interpreting past actions (Weick, 2001, p. 182). This is not to suggest that institutional myths are not "real" or that they do not represent what is "true." On the contrary, myths are far from unreal; they offer powerful and coherent narratives that both explain and guide social behavior. That these myths may be accepted uncritically, or simply through their connection to other important myths, does not mean that they are false. To the contrary, the myths embody abstract social values and represent them in an exemplary form, thereby resolving the contradictions that emerge in practice (Eliade, 1963). In the case of online education, the function of the myth is strictly sociological, "supporting and validating a certain social order" (Campbell, 1988, p. 31).

\section{THE ONLINE DIVIDE: AN INSTITUTIONAL EXPLANATION}

The CCRC data reveal that the colleges in the study have adopted the features of online education in highly visible ways, in order to maintain the "logic of confidence" upon which their legitimacy as real colleges depends (J. W. Meyer \& Rowan, 1977). This proved true even at colleges where administrators claimed not to be promoting online expansion. The meaning of online education has been constituted within a changing postsecondary landscape, and these colleges are in the midst of responding to the changing conditions and shifting social definitions. This means that college-level actors must make sense of and respond to new environmental pressures 
(Weick, 1969). As they do so, their decisions are guided by institutional myths and their concern for organizational survival.

Indeed, colleges' adoption of online education has been structured by a set of taken-for-granted assumptions, largely unsupported by empirical evidence, but perpetuated by faith in the myth of online education. The rhetoric of community college administrators illustrates the basic contours of the myth and the ways that the ritual language, which articulates the goals of colleges' online involvement, draws strength from its integration with other fundamental myths.

At the same time, as the core work of providing online courses is carried out by online coordinators and instructors inside the colleges, the symbols of online involvement remain distinct and disconnected from actual online practices. This disconnect serves a crucial function, since stronger links between the visible symbols of online education and the core work of offering online courses could expose significant contradictions, thereby threatening community colleges' legitimacy.

\section{THE MYTH OF ONLINE EDUCATION}

The majority of upper-level administrators at 14 of the 15 colleges ${ }^{13}$ consistently reiterated the same mantra of online education. The mantra reflects the emergent "facts": the utility of online education in serving postsecondary students' demands and interests, the need for colleges to embrace online education to survive challenges from the competition, and the transformation of teaching and learning being effected by the new digital media. In this way, the construction of "online education" is integrally linked to three other institutional myths: "access," "competition," and "technological literacy" (Figure 3).

\section{RITUALS OF ACCESS}

The ritual language of online education highlights the community college's unique mission to provide wide access to postsecondary education. The administrators we interviewed uniformly linked their advocacy of online education to a concern with democratic educational opportunity, linking online involvement to the college's role in enabling postsecondary access to "nontraditional" students. For instance, according to one college president,

We are putting a tremendous amount of emphasis on technology.... As an access tool definitely, to get students who are place-bound, jobbound, child-bound, an opportunity to get back in the classroom from 


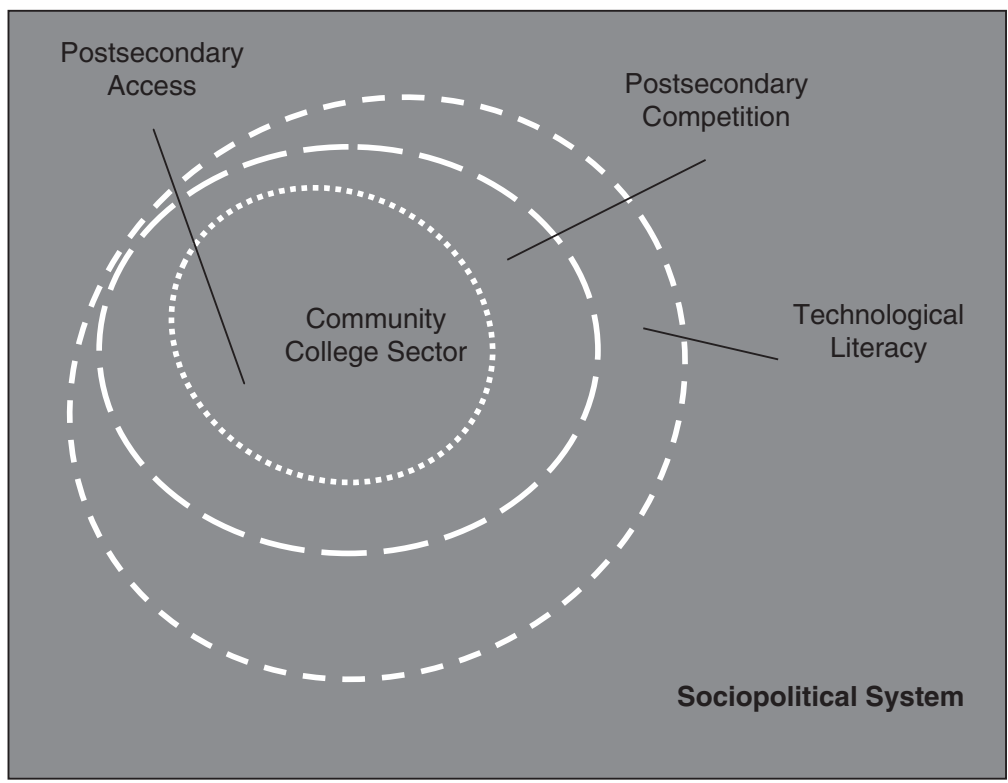

Figure 3. The Community College and Institutional Myths

their homes by using technology - whatever avenue it takes to get the education/get them educated to a higher level.

Fundamentally, administrators viewed the adoption of online education as an absolute necessity. As one administrator described this imperative, "you'd have to be blind not to see it."

However, in spite of passionate descriptions from senior administrators at nearly every site about the college's commitment to expand student access through online offerings, the extent of colleges' involvement was generally modest. As mentioned earlier, even at the high end of online involvement, colleges were in the preliminary stages of constructing programs. Furthermore, the story of increased student access was undermined by the enrollment data. For example, at each site, the majority of students in online courses also enrolled in on-site classes. This meant that, for the most part, the online courses were fulfilling the demand for convenience, rather than access. Significantly, administrators at several colleges noted that future online courses would most likely not draw new students from their service area. In two cases, the key factor was the low proportion of residences with home computers; at one of the rural colleges, low-capacity phone lines limited the potential for online communication. In practice, then, increased access has increased the colleges' enrollment numbers but 
has not necessarily enabled access for students otherwise unable to attend the college.

At several sites, the bulk of student enrollment in online courses occurred after on-site sections had filled, suggesting that students would have preferred to take the face-to-face versions. Indeed, the online coordinator at one such site lamented this pattern, since the students who enrolled at the end of the registration period tended not to be the motivated and selfdisciplined students who have enjoyed the most success in online courses. Indeed, students' lower completion rates in online courses than in on-site ones does not support the notion that online courses increase students' educational opportunities. In sum, administrators were invoking the democratic aspects of online education - with utmost sincerity - even as college practices revealed conditions that were not resulting in enhanced educational opportunities.

\section{RITUALS OF COMPETITION}

Respondents at our sample of community colleges consistently reiterated the pressures of competition in explaining the college's involvement in online education. At a suburban college in New York, ${ }^{14}$ for example, one administrator commented, "I think we need to do more [distance learning] in order to stay competitive. We're going to get knocked out of the box if other community colleges or other state ops or other states start taking over our territory." At another college, an administrator expressed concern that local proprietary schools would "eat our lunch."

As subordinate members of higher education, community colleges face immense competitive pressure, and such statements reflect the increasingly market-oriented postsecondary environment. In the face of decreased federal and state funding, public colleges and universities have been forced to rely on the private sector for an increasing proportion of resources. At every level of higher education, the result has been an intensification of competition for critical resources: funding, student enrollment, and status. Within the community college sector, the typical enrollment-based funding procedures at the state level spur colleges to continually seek higher enrollment numbers. In conjunction with the increasing demands for resource efficiency and accountability from state legislatures, maintaining the college's market share is a crucial and ongoing concern for administrators.

Within this increasingly competitive environment, the proliferation of postsecondary proprietary schools has presented a new threat to community colleges. This new source of competition has ratcheted up the fear of losing future enrollments, resulting in the inevitable isomorphism as community colleges identify and adopt the distinctive features of the new postsecondary providers (DiMaggio \& Powell, 1991b). The distinctive 
proprietary-school practices include a faster rate of degree completion, more convenient course scheduling, and the provision of business and technology education (Bailey, Badway, \& Gumport, 2003). Armed with this understanding of the proprietary innovations, community colleges have incorporated changes in on-site course schedules ${ }^{15}$ and begun to view online education as a way of offering the technology-oriented coursework and the convenience of the for-profit schools.

Additionally, as the community colleges in the study developed their initial online offerings, they were bombarded by the persistent rhetoric from the business world, which avowed that Internet-savvy education providers would capture a crucial share of the educational market. This notion was promoted in various forums, including the educational policy discourse, as in RAND analyst Walter Baer's (1999) contention that

some institutions undoubtedly will be squeezed out by more entrepreneurial competitors, both nonprofit and for-profit. For e-learning, as for other sectors of E-commerce, the Internet rewards those who enter early, adapt rapidly and are ready to seize opportunities as they arise.

That public rhetoric has subsided, but the language at the community college level continues to portray online education as a key to maintaining a competitive edge. Indeed, this particular construction of online education - as a key to success in the postsecondary market - is immensely powerful, because it is integrally linked to the fundamental sociopolitical myths that buttress the state and its economic structure.

The realities of competition at these colleges, however, have not been congruent with the ritual language. While some statements about competitors sounded reasonable, other references to online competition were more fanciful. For example, an administrator at one of the colleges with minimal capacity described her vision of the college's online future:

I just read in the Chronicle [of Higher Education] today that the University of Phoenix sold their distance ed company for $\$ 70$ million. They've been very successful and ... I think if we start looking at Phoenix University and National University and [the Open University in] England and some of these other places that have been very successful, then the breadth of what we can do is very large.

Perhaps this statement is the inevitable outcome of the hype surrounding online education. Because the reality pales next to many of the initial claims for online education, realistic predictions of the future may not be enough to justify the huge investment of resources required to build and maintain 
an online program. For instance, the lore of Open University's (OU's) success with online education exceeds the facts; OU has successfully created programs that for the most part can be completed at a distance, but most courses do require on-site meetings, and the most common instructional media are not Web-based, consisting instead of video and computer-based programs. ${ }^{16}$ As of 2000, OU offered only five courses online. In fact, a closer look at OU's distance education curriculum highlights the impossibility of community colleges' realizing distance courses like OU's. In terms of course development in the technology department at Open University, the time devoted to creating a new course can span up to 4 years and cost $\$ 2.5$ to $\$ 3.5$ million (Grose, 1999).

In respect to the competition from the growing number of proprietary colleges, the reality is that the private, for-profit universities such as Phoenix University and National University do not serve the students whom community colleges tend to enroll. The higher tuition and limited degree programs of the University of Phoenix contrast sharply with the lower cost and more comprehensive mission of the not-for-profit 2-year sector. For instance, for the many students who are uncertain about their educational goals, conducting low-cost "experiments" at the community college is the best choice (Grubb, 1996, chap. 2).

In fact, when asked explicitly to describe the college's relationship with other educational providers, administrators without exception dismissed any suggestion of competition with proprietary schools. To the contrary, several colleges had established informal partnerships with local campuses of proprietary schools, providing evidence that those for-profit colleges are interested in enrolling community college students-but only after the students complete their community college coursework. Leaders at several other colleges noted that they had been approached by the University of Phoenix to build collaborative connections but had declined the invitation. And although the growth of the for-profit sector has garnered public attention, data from the Integrated Postsecondary Educational Data System indicate that the for-profit sector is "only a minor player among two-year institutions" (Bailey et al., 2003). While the number of for-profit, 2-year colleges has risen over the past decade, the enrollment numbers have not; between 1993 and 1998, the proportion of for-profit enrollments among 2-year colleges actually decreased, from 4.1 percent to 3.9 percent (Bailey et al., 2003).

\section{Competition as Legitimating Discourse}

Thus, the evidence of proprietary competition is insubstantial, at best. However, the threat of proprietary competition has entered the community 
college as the legitimating discourse - the rationale with the most power to persuade community college actors and effect organizational changes. References to competition have become the rallying cry when administrators discuss the need for action on a range of issues beyond online education, illustrating Brint and Karabel's (1991) contention that "weak competitors ... tend to accelerate change by providing an external threat against which administrators can rally support" (p. 355).

As one group of faculty members explained, their college's involvement with online education is part of the "business" of education: "we were told when we first got started, that these private schools are all getting into this, and we have to do it. A certain aspect of it is that it's a business; you have to stay competitive." ${ }^{\prime 17}$ At this particular college, the administration was relying almost solely on online education to drive an enrollment increase of over $10 \%$ over the following year. The primary impetus for expansion was located in the mechanics of state funding - in which exceeding the growth target would result in a permanent (and substantial) expansion of the college's resource base. In explaining the rationale for online expansion, a senior administrator shared the following information during an interview:

Administrator: We were in a situation where we really wanted to start generating some growth. Increase our numbers. And be able to deliver more classes throughout our district. And being a rural district, any form of distance education seemed to be the answer.

Interviewer: Did you do any kind of a study that would indicate that online education is a way to [increase enrollments]?

Administrator: Well, not a formal study, no. Looking at some other models in the state, there are some other rural colleges that have had tremendous success with online education.

Despite the immense influence of local conditions on community college planning, this administrator had not investigated the specific details of the other colleges' online involvement or compared the local conditions among the colleges. Even without empirical data, the plan to increase enrollment through online courses maintained an unequivocal logic. Similarly, at a second college endeavoring to expand online offerings as quickly as possible, respondents described the college's objective: to become one of the five largest colleges in the state. Buoyed by indicators that the state universities planned to lower their caps on freshmen and sophomore admissions, senior administrators planned to capture the surplus enrollment through their online program.

In sum, the discourse of competition is not unrelated to the challenges of functioning in a low-resource field. However, the evidence indicates that 
competition pits community college against community college, while the discourse appeals to the image of the public (democratic) college holding its ground against the new for-profit providers. At the same time, formal leaders at these colleges have drawn on the ritual language to describe new organizational objectives. In this way, individuals at the organizational level have been able to capitalize on a powerful, multifaceted institutional myth in promoting expansion (or other organizational changes).

\section{The Power of Myth}

Ultimately, actors at all 15 colleges have responded to the intertwined myths of competition and online education. By shaping the perceptions and decisions of college stakeholders, the myths have exerted a strong influence on colleges' online involvement. For the colleges that have been able to assemble the components of online capacity, the results have indeed enabled the colleges to maintain (or increase) their positions within the educational market. For the three colleges with minimal online capacity, the failure to incorporate online course structures (as of 2000) has had grave consequences.

At CU, despite district-level pressure to build an online program, a fundamental lack of administrative capacity had prevented much progress. Once the college lost the bid for an important (and anticipated) military contract to the other college in the district, several administrators focused their attention on online course development. Their efforts, however, did not alter the district-level dynamics, which have facilitated further expansion of the other college's online program and, by virtue of that online growth, the accrual of additional resources. In contrast, CU's low online capacity has limited its ability to attract an adequate level of investment from any source. As of fall 2002, the college was able to offer only three online courses. By losing the initial contract, the college suffered two losses: one financial and one of status. In signaling a low level of online functioning, the college has been further disadvantaged in its district-level competition for resources.

WR, a small rural college, had faced similar challenges in offering online courses. Very few faculty members were interested in exploring online instruction, and the college's financial resources were already stretched very thin. At the time of the site visit, the college was already facing unfortunate repercussions. Over the previous semester, the combination of minimal online offerings and the calculus of state funding had forced the college to pay $\$ 16,000$ to another community college in the state for the provision of online courses over a single semester. ${ }^{18}$ In effect, both of these colleges - struggling to move beyond a low level of online capacity-have faced financial sanctions for being particularly low-resource organizations. 
In the abstract, postsecondary competition is thought to push colleges to become more efficient and effective. Those revealed as poorly functioning colleges therefore become accountable to students and are compelled to improve their organizational performance in order to survive. In practice, however, the competitive pressure to build online programs has had much more invidious outcomes. First, the crucial competition-among community colleges - forces the colleges to scramble for public funds that, even if allocated more equitably, are woefully inadequate. ${ }^{19}$ Second, each college's online capacity is most strongly linked to the status of its student population, not its performance in meeting its key missions. ${ }^{20}$ Ultimately, this competition serves a fundamentally antidemocratizing function.

At CS, the one college where administrators explicitly denied any interest in online education, the college's position in the market precluded the need to embrace online courses as a competitive strategy. For that college, a suburban college located in the most affluent region of its district, enrollments have been increasing steadily. As a result, senior administrators have been able to invoke its concern with high-quality teaching when explaining its disinclination to expand the online program. It is likely that without the college's advantaged position in the competition for district resources, it would promote online expansion more enthusiastically.

Furthermore, the situation at CS illustrates the division between online capacity and actual organizational performance. Despite administrators' dismissal of the value of online education for student learning, the college does offer online courses, and their availability is highlighted on the college's Web site. Again, the existence of online offerings lends the college status as a technologically up-to-date organization. Thus, CS is playing by the institutional rules, signaling its online involvement. Yet the actors at the college explicitly avowed that there is no direct connection between online education and the organization's performance of its core work (teaching).

\section{RITUALS OF TECHNOLOGICAL LITERACY}

The primary language that senior administrators employed to describe the benefit of online education for students linked online education with the myths of access and competition. In that formulation, the benefits include the increased convenience of taking classes "anywhere, anytime" and the increased access to postsecondary education for nontraditional students. Such access increases students' opportunities to acquire postsecondary credentials and in turn contributes to increased economic opportunities in the labor market. Also embedded in this vision of online education is the assumption that online education fosters students' acquisition of the technology-related skills required in the workplace. In one version of this vision, 
administrators explicitly described the educational value of using Webbased technology as a means for students to pursue careers in high-technology fields.

In this way, the advantages of online education are linked to a third institutional myth: that of technological literacy. The basic outline of the technological literacy myth is founded on the premise that students need to be able to function in this increasingly information- and technologically rich world. Those functional skills enable individuals both to pursue lucrative careers and to contribute to the highly skilled workforce necessary for continued national health. Presenting technological literacy as an educational necessity, the wide-scale educational initiative of the 1990s proposed this definition: "Technological literacy - meaning computer skills and the ability to use computers and other technology to improve learning, productivity, and performance - has become as fundamental to a person's ability to navigate through society as traditional skills like reading, writing, and arithmetic" (Getting America's Students Ready, 1996, quoted in Selfe, 1999, p. 5). In the wake of the national literacy project, this particular construction has become embedded in the educational system, most explicitly in state-level curriculum frameworks for grades K-12 (Selfe, 1999), but also implicitly, throughout a variety of educational discourses. As a result, within the widely accepted definition of technological literacy - primarily as the use of digital technology - the issue of how digital technology might improve "learning, productivity and performance" remains unstated. This, in turn, accommodates more complex visions of the benefits of technological literacy without defining or explaining the connections. In other words, the technology itself has become a symbol of the myriad unsubstantiated claims embedded in the literacy myth.

From the outset, the discourses of public policy, higher education research, and news media have suggested multiple ways that online education is transforming education. References to the advances in digital technologies presuppose that Web-based media have profound pedagogical implications. In this way, the ongoing advances in multimedia digital technologies - which are indeed tremendous-support the notion that when harnessed to educational applications, the result is a transformation in teaching and learning. Consider Twigg's (2002) description, within an argument about the transformation of postsecondary schooling:

Digital learning applications are steadily improving. Search tools that enable complex and stored queries, as well as automated updates are developing rapidly. Web-enabled presentation is becoming easier to use while facilitating the communication of ideas and information in ever more powerful ways. Hybrid CD-ROMs provide the multimedia richness of CD-ROMs and the up-to-date 
capabilities of Web sites. Real-time audio and streaming video can now be delivered through standard 56 kbps. Virtual reality applications will offer additional enriching tools. Interactive databases, spreadsheets, and Java applications engage users with customized exercises, demonstrations, simulations, and tests. (p. 85)

Indeed, such digital applications could have astounding pedagogical implications. But under what conditions? For what kinds of instructional objectives? By employing what kinds of pedagogical knowledge?

In the end, the myth of technological literacy suggests direct, immediate links between the use of digital technologies and a highly productive learning experience. This implicit link enables the technology itself to function symbolically, whereby the presence of digital technology signifies the great learning experience. This myth has significant implications for both on-site and online classes. Even prior to colleges' online involvement, enrollments in information technology classes had soared, in part because colleges have been able to market their information technology offerings as valuable career-related courses. ${ }^{21}$ The vast majority of these courses focus on the use of software, typically Microsoft Word and Excel. Two questions emerge. First, to what extent does taking these classes, or even earning the Microsoft Office Specialist certification, increase a student's employment options? ${ }^{22}$ Second, what kind of technological literacy do these classes afford: competent use of the software, or a more sophisticated understanding of its use (what Selfe terms critical technological literacy), one that facilitates the acquisition of advanced technological skills as well as a more critical perspective on the uses of technology (Selfe, 1999, p. 148)? ${ }^{23}$ In fact, it may be just as useful to question the most common professional development courses aimed at increasing the instructional use of technology (e.g. "How to Use Powerpoint").

These questions are equally relevant to colleges' involvement in online education. The perceived link between important job skills and the use of digital technology reinforces the notion that Web-based courses facilitate student learning. In this construction, one valuable aspect of online education for students is the opportunity to use Web-based technology; thus the use of digital technology is the focus, rather than how that technology is used. This enables the clear distinction between the existence of an online course and the dynamics of online communication within the course. In other words, the online course has become "institutionalized product" (J. W. Meyer \& Rowan, 1977, p. 340). The symbols of online involvement (the evidence that the online courses exist) have taken on a complex set of institutional meanings, which ultimately are disconnected from actual online practices and the quality of learning resulting from those practices. $^{24}$ 


\section{IMPLICATIONS}

From the perspective of institutional theory, the inconsistencies between a college's visible enactment of the online education myth (through ritual performances and symbols) and the actual practices of the college's online program are not surprising (see Figure 4). Given that the intertwined institutional myths emerged from conflicting sociopolitical values, the likelihood of their contributing to an improvement in the actual work of teaching and learning was slim, at best. At the same time, for the adoption of institutional rules to legitimate an organization's status, the contradictions between the institutionally generated forms and the core work activities must remain invisible.

In the case of colleges' online adoption, three mechanisms have enabled the division between ritual performances and actual online practices. First, online education has been defined as a technological product, rather than an interactive or relational process. The existence of online courses (i.e., the use of digital technology) is central; the substance of what happens inside the courses is peripheral. This, in turn, means that the assessment of the online program or of the individual online courses focuses on the technological components, rather than the processes of teaching and learning that constitute the online courses and the online program. Indeed, a consistent feature across every college was the scarcity (or more frequently, the complete absence) of assessment data for online courses. Although colleges maintained records of online enrollments and retention rates, the work of

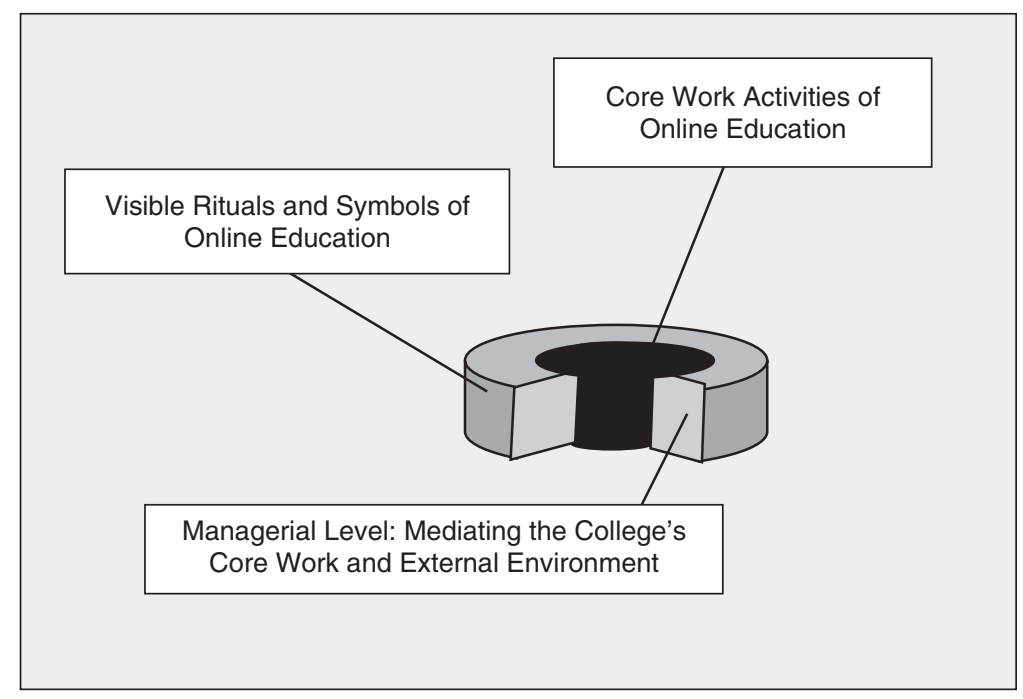

Figure 4. Community College Organizational Structure 
evaluating and improving the quality of courses was, at best, in a preliminary stage. Furthermore, at nearly every college, although administrators expressed deep concern with the consistently low retention rates in online courses, none of the colleges had analyzed the problem, thereby avoiding any documentation of contradictions between the institutional myth and the organizational realities.

And finally, the conceptualization of online education, neatly separating the online components from the instructional practices, leaves the online faculty (and coordinators) to work out the practical complications of developing and teaching courses with very little organizational assistance. And although the faculty and coordinators have been working very hard in their efforts to offer high-quality online instruction, the institutional imperative to provide online education has taken precedence over most considerations of teaching and learning quality. Thus, the issue of quality, while of great concern, has been subsumed by the logistics of getting those courses online. Furthermore, the nearly exclusive focus on structure at the organizational level has reified the conception of Web-based technology as a "delivery" system. Within such a framework, online teaching consists of "delivering" instruction or transmitting course content. Indeed, the virtual classrooms observed in this study were highly text-oriented, with the substance of the course comprising that text-based information. In some cases, students were able (or required) to buy document packets (print-based) that contained identical information to that on the Web site. In these cases, Webbased technology truly served as a delivery system. With respect to the quality of the resulting courses, one online coordinator commented,

Probably the same range of practice that we have in our face-to-face courses is being replicated online, when that might have been an opportunity not just to teach people technology, but to have them think about engaging students and what kinds of things you can do better online, rather than just post your lecture, or whatever it is that might be happening.

Although the work of online faculty members is not determined by these institutional conceptions and organizational structures, they place constraints on understanding how to wed instruction and technology. The most compelling example consists of the learning opportunities that faculty are afforded. The dominant paradigm for course development at these community colleges has structured professional development as opportunities for instructors to learn how to use the technologies that comprise the "delivery system." One instructor explained the inadequacy of such an approach: 
I took a course on Web CT ... and it was glaringly obvious from the moment I walked in that the course was taught by someone who knew the technology inside out and backwards, but had no sense of how to communicate that material. No sense of what classroom assessment is about or how to get input from the students.

Individuals at every college are challenging that paradigm, and increased concern with the quality of classroom-level learning and greater understanding of the immense challenges of online teaching has led online coordinators to provide more robust opportunities for faculty learning. In the end, however, the resources the colleges are able to draw upon do not offer faculty the kinds of expertise or afford them the learning opportunities that would allow them to rethink or redesign their curricula.

These findings echo the work of other researchers who contend that online courses throughout higher education do not reflect dramatically different approaches from on-site courses. In reference to an extensive body of research on learning processes, Bransford, Vye, and Bateman (2002) note that instructors who are asked to imagine one of their current courses as an online one consistently envision an online version that results from transferring the classroom-based course to the Internet. In fact, the authors assert that when asked to redesign the lesson for any course (whether on-site or online), every individual can suggest improvements, but only rarely does an instructor redesign the course (e.g., rethink the use of a lecture-driven format). As a result, "most online courses have tended to look much like 'porting' existing classrooms onto the Internet. From the perspective of HPL [the How People Learn framework], neither traditional face-to-face courses, nor their online cousins, represent environments where opportunities for high-quality learning are consistently strong" (Bransford et al., 2002, p. 190).

In other words, there is an immense difference between putting a course online and redesigning a course by starting from the learning goals and integrating various forms of knowledge and expertise to build a course that realizes those goals. However, redesigning courses is far from simple and requires expertise that may be distributed among different individuals (e.g., knowledge of the subject matter and learning, expertise in assessment practices and technology). However, the resource supports and organizational structures that would facilitate a truly different approach to faculty learning, course development, and online instruction are absent from every college. Thus, despite the determined (and in some cases, heroic) efforts of individual faculty and online administrators, the kind of organizational communication and coordination needed to support such an approach - both within the college and with the external environment - is missing. More significantly, to build those structures would 
create a fundamental challenge to the ceremonial structures of online education.

In sum, Web-based communication could potentially support a rich educational experience in virtual classrooms. Doing so would require the fundamental redesign that Bransford et al. (2002) discuss, starting at the core interactive processes of teaching and learning and building structures that support those priorities and needs. Ultimately this would involve institutionalizing a more sophisticated approach to both on-site and online education. But the ceremonial structures adopted by community colleges and the myths that have generated the meaning of those symbols present a sprawling obstacle to doing so.

At the same time, the obstacles are not insurmountable. Certainly, powerful institutional myths have shaped the "facts" or social meanings of online education, and indeed, it has become a required component of community colleges' curricular programs. Furthermore, the disconnect between ritual symbols and core practices enables low-quality online practices to flourish. However, the disconnect also provides the online coordinators and instructors with some measure of discretion in assembling and expanding an online program. In the case of online education, the institutional rules focus on the ends of colleges' online involvement, but not on the means. Under these conditions, in which neither the technical knowledge base nor the institutional beliefs about the means are well elaborated, the level of uncertainty is relatively high (Goodrick \& Salancik, 1996). "Existing alternatives may then be selected without loss of legitimacy. With the discretion resulting from uncertain prevailing institutional standards, organizational or individual interests may frame strategic choices" (p. 4). Thus, the uncertainty increases the potential for alternative online practices.

Not surprisingly, faculty members were the interview respondents who were most likely to question the ceremonial activities of the colleges' online programs. For instance, an interdisciplinary group of faculty mentioned discomfort with the current administrative pressure to put courses online. "There's a lot of talk about modularizing our courses and putting them online and teaching components. Many of us who take more of a holistic perspective in course curriculum are finding ourselves having a hard time with that piece." Underlying that concern, and other similar comments, was the feeling that instructional integrity and course quality are at stake in the online marketplace. One of the original online instructors at a different college spoke of his online teaching and course development experiences in the context of changing organizational priorities. Describing this ongoing change, he explained, "There's a real emphasis on cost savings, and there just seems to be no serious attention to academic issues. ... There's been a shift, from regard for academics to a regard for fiscal control." 
Often, the interview respondents who expressed the most criticism of online educational quality were individuals with the most experience in their college's online program, as online coordinators, online course developers, or online teachers. Citing a range of problems affecting course quality, such respondents also noted their concerns for the future. For instance, after describing her college's online program as a means of transmitting information, one instructor remarked:

I think there are some of us, myself included, who believe that there is a very, very different emphasis in education as opposed to information, and I don't want us to lose a sense of that distinction - that you can inform a person without really educating them. Giving a person information doesn't help them know what to do with it, and we are a very, very information-rich society as it is, with a lot of people who don't know how to apply information, who cannot synthesize.

For this instructor, the current trajectory of online "education" at her college emphasizes information, not education. For her current students, the online rituals of access and technological literacy may, in the end, constitute only superficial experiences of postsecondary access and technological literacy. As long as such outcomes remain hidden, the myth of online education can legitimate colleges' online involvement.

\section{CONCLUSION}

In the final analysis, the myth of online education has exerted a strong antidemocratizing influence on these community colleges. Although the college-level actors maintain relative autonomy in respect to the institutional pressures, constructing high-quality virtual environments demands a variety of resources and knowledge largely unavailable within individual community colleges. Consequently, while the colleges spend efforts making incremental (albeit necessary) improvements to their online programs, the current trajectory of online involvement can only exacerbate existing postsecondary educational inequities. Perhaps the blithe assumptions about "e-learning" hold true for high-status colleges and more advantaged postsecondary students. But without empirical evidence about exactly how and under what specific conditions online processes facilitate robust learning, the promises of online education are unlikely to be realized at the community college. Fundamentally, the possibility of a more equitable path of online development depends upon making the practical realities more transparent and reducing the disconnect between the myth and the practices. 
This study was funded by the Alfred P. Sloan Foundation. However, I claim sole responsibility for the argument presented in this article. Many thanks to the other members of the research team, especially Vanessa Smith Morest. I would also like to acknowledge the helpful comments I received on earlier drafts from Marnie Curry, Judith Warren Little, Jennifer Russell, Maika Watanabe, and two anonymous reviewers.

\section{Notes}

1 I will employ the terms "online education," "online courses," and "online programs" in an effort to minimize drawing on the ritual (ideological) aspects embedded in other terms.

2 Some reports of Web-based education conflate different levels of Web use, grouping courses with minimal Web use - such as course Web sites and peripheral e-mail use - together with courses in which the majority of instruction occurs in the virtual classroom. For this study, we defined an online course as one in which $95 \%$ of instruction occurred at a distance. Thus, courses with an initial on-site meeting are considered "online." We also made note of other distance courses, especially those using newer technologies. Several colleges had invested in interactive instructional television courses, but the focus of efforts in new forms of distance education - even at those sites - was on online education.

3 The full list of research topics consisted of (a) accountability and performance-based funding, (b) counseling and student support services, (c) developmental education, (d) distance education, (e) K-14 partnerships, (f) the multiple missions and roles of community colleges, (g) the rise of new competitors, and (h) workforce development and industry certifications.

4 In selecting transcripts to read, I searched the interview database for all references to information technology, distance education/distance learning, online education/online learning, computers, computer skills, and computer/technological literacy. Although I read all the transcripts of student interviews, they did not contribute any insights to this analysis.

5 This is not to suggest that other faculty members at these colleges did not exhibit these characteristics in other areas of practice. We saw evidence of innovation - both technologyrelated and not - on the part of many instructors who were not involved in online education.

6 Rogers's (1962) theory of diffusion involves discussion of individuals who are likely to be early adopters of innovative practices, revealing distinct differences among individuals' approaches to new technologies. Applying Rogers's heuristic, Garofoli and Woodell (2003) estimate the following distribution of faculty among Rogers' categories: innovator (2.5\%) early adopter $(13.5 \%)$, early majority (34\%), late majority (34\%), laggards (16\%). In their discussion of the dividing line between "early adopter" and "early majority" faculty, they note the typical characteristics of early adopters as "visionary," "risk-takers" who "favor revolutionary change," "willing to experiment," and "generally self-sufficient. In contrast, "early majority" instructors are typically "pragmatic," "risk averse," in favor of "evolutionary change," "want proven applications," and "may need significant support."

7 These abbreviations have been assigned to maintain the colleges' anonymity. The labels chosen locate them geographically. For example, CU, CS, CR are the three colleges in California - one urban, one suburban, one rural.

8 The notion of becoming a "learning college" has been developed through a particular body of community college literature. The Vanguard Learning College Project sponsored by the League for Innovation in the Community College provides one example of these initiatives. For more information, see the League's "primer" (2004), introduced with: "Many colleges are interested in becoming more learning centered and have asked for help in where to begin. The Learning College Primer offers a set of foundational resources colleges may find valuable as 
they begin the Learning College journey. The primer includes publications that provide fundamental information about learning, the Learning College, and the Learning Revolution."

9 In fact, during individual interviews, several senior administrators explained that, after investigating the issue, they deemed Web-based education an unprofitable investment. However, this verdict did not entail a wholesale rejection of all distance education: They had devised a strategy for expanding their distance education program through a more profitable approach, involving the purchase of prepackaged curricula on videotapes.

10 See Jepperson and Meyer (1991) for an interesting discussion of the modern polity as an institution and the characteristics of the knowledge system underlying different versions of that institution.

11 Here I draw on David Labaree's (1997) formulation of these competing purposes.

12 The argument could also be made that in addition to channeling students into midskilled employment, community colleges also provide labor for the low-skilled labor market, since the attrition rate-both in individual courses and in degree programs - is so high.

13 The only exception in this instance was CS. FMU proved not to be an exception: While the president had expressed a strong desire to cut down the online offerings, the majority of senior administrators did not express that view.

14 New York was the one state in the sample that had not established service districts for online providers. In other states, community colleges had formed consortia and as a collective group negotiated the terms by which one college's student enrolls in an online course offered by a different college in the state. These alliances of community colleges across each state have thereby addressed the colleges' fundamental fears, those of lost enrollment and decreased funding.

15 Changes include shorter course terms, night and weekend courses, and informal certificates illustrating students' progress (marking an arbitrary point of completion-often the completion of a specific number of units).

16 The quality of teaching in OU courses has been rated highly by the Higher Education Funding Council, offering some measure of quality of its distance course curricula. In the context of quality, note the description provided by Martin Solomon (former Vice Provost at the University of South Carolina) on the challenge of developing good courseware: "Developing quality multimedia courseware is too difficult for 98 percent of all faculty. Watch the end of a movie next time and notice that to produce 120 minutes of interesting material it required 100 different people at a cost of, say $\$ 15$ million. A typical higher education semester comprises over 2,000 minutes of material. Reasonably, a meaningful amount of multimedia content might cover 10 percent of the course. That comes to 200 minutes - much more time than a multimillion dollar movie" (quoted in Delong, 1997).

17 Despite "acceptance" of this part of myth, this faculty, as a whole, was highly resistant to online teaching. As a result, administrative strategies for increasing the number of online instructors involved hiring out-of-state instructors and making full-time employment of new hires contingent on their willingness to teach online courses.

18 WR's solution to this financial burden involved collaborating with another rural college in the state. This was the only example in the study of inter-college collaboration in process.

19 See, for instance, Grubb and Associates (1999) for a brief discussion of the "substantial basis" for community college complaints of being underfunded (p. 322).

20 Kevin Dougherty's analysis of state-based accountability measures indicates that performance-based funding is in its initial stage; the outcomes measures used by the states in the study were often not well matched with the colleges' educational objectives (Dougherty, in press).

21 See Brint and Karabel (1989) for a historical discussion of community colleges' efforts at marketing (p. 126), as well as colleges' efforts in the 1980s to become a major provider of high- 
tech career training, despite the evidence that employment in that sector would not account for a particularly high proportion of jobs (p. 132).

22 As far as the value of community college credentials in the labor market, Grubb's (1996) study of four local labor markets (including San Jose) offers germane insights. Employers interviewed as part of the study consistently expressed their desires to hire individuals with highly job-specific skills. In most cases, applicants with job experience were valued more highly than those with subbaccalaureate credentials. As a manager in a high-tech firm remarked about postsecondary education in general: "It comes to the reward that you will get from attending these classes or education. And the answer is zero. You do not get a financial reward for attending any class. You do not get any financial reward for showing proficiency through attendance at educational universities. You do get financially rewarded for performance, which perhaps is enhanced by having a better education. You do get financially rewarded for results, which again may be enhanced by having a broader knowledge of the subject" (pp. 37-38).

23 Also applicable is Brint and Karabel's (1989) definition of critical literacy as "involving high levels of independent thinking' (Richardson et al., 1983, p. 5). We define the cultivation of critical literacy as 'the capacity and inclination to think critically and act on the basis of informed judgment' (see Katz, 1982, p. 194)" (Brint \& Karabel, 1989, p. 231).

24 In fact, the symbols of a college's online participation appear in numerous forms, including (a) prominent mention of the online program on the college's home Web page, (b) the set of Web pages devoted to the procedures and guidelines for potential online students, (c) reference to the course management system that the college has adopted, (d) the number of online offerings, (e) the online course descriptions, (f) courses in the class schedule that are clearly marked as Web-based, and at some colleges, (g) additional texts: brochures, separate online course schedules, lists of frequently asked questions, etc. In addition, state- and regionallevel consortia advertise the college's online involvement. The visible evidence of these consortia activities takes the form of a Web site that consolidates the information about online courses for students. This makes the registration information available to students in one spot, while announcing each college's participation in online education. Using the Internet to document the availability of online courses across the state serves as a ritual of legitimation for the individual colleges and for the colleges as a collective group. At this symbolic level, a college's investment in online education represents a legible sign that the college is embracing cuttingedge developments and is attentive to the needs of 21 st-century students. It should not be surprising that every college, regardless of the state of its online capacity, has made efforts to incorporate the symbols of online education.

\section{References}

Baer, W. (1999). E-learning: A catalyst for competition in higher education. IMP Magazine, 9(2), Retrieved from http://www.cisp.org/imp/june 99/06 99baer.htm

Bailey, T., Badway, N., \& Gumport, P. (2003). For-profit higher education and community colleges. National Center for Postsecondary Improvement. Retrieved February 20, 2003, from http:// www.stanford.edu/group/ncpi/documents/pdfs/forprofitandcc.pdf

Berger, P. L., \& Luckmann, T. (1967). The social construction of reality: A treatise in the sociology of knowledge. New York: Anchor Books.

Bransford, J., Vye, N., \& Bateman, H. (2002). Creating high-quality learning environments: Guidelines from research on how people learn. In P. A. Gram \& N. Stacey (Eds.), The knowledge economy and postsecondary education: Report of a workshop (pp. 159-198). Washington, DC: National Academy Press.

Brint, S., \& Karabel, J. (1989). The diverted dream: Community colleges and the promise of educational opportunity in America: 1900-1985. New York: Oxford University Press. 
Brint, S., \& Karabel, J. (1991). Institutional origins and transformations: The case of American community colleges. In W. W. Powell \& P. J. DiMaggio (Eds.), The new institutionalism in organizational analysis (pp. 337-360). Chicago: University of Chicago Press.

Burbules, N. C., \& Callister, T. A. (2000). Universities in transition: The promise and the challenges of new technologies. Teachers College Record, 102, 271-293.

Campbell, J. (1988). The power of myth, with Bill Moyers. New York: Random House.

Clark, B. R. (1970). The organizational saga in higher education. Administrative Science Quarterly, $17,178-184$.

Cohen, A., \& Brawer, F. (1996). The American community college (3rd ed.). San Francisco: JosseyBass.

Council for Higher Education Accreditation. (2000, April). Distance learning in higher education. CHEA Update \# 3.

Delong, S. E. (1997). The shroud of lecturing. First Monday, 2(5), Retrieved from http:// www.firstmonday.org/issues/issue2_5/index.html

DiMaggio, P. J., \& Powell, W. W. (1991a). Introduction. In W. W. Powell \& P. J. DiMaggio (Eds.), The new institutionalism in organizational analysis (pp. 1-38). Chicago: University of Chicago Press.

DiMaggio, P. J., \& Powell, W. W. (1991b). The iron cage revisited: Institutional isomorphism and collective rationality in organizational fields. In W. W. Powell \& P. J. DiMaggio (Eds.), The new institutionalism in organizational analysis (pp. 63-82). Chicago: University of Chicago Press.

Dougherty, K. J. (1994). The contradictory college: The conflicting origins, impacts and futures of the community college. Albany: State University of New York Press.

Dougherty, K. J. (in press). Performance accountability as imperfect panacea: The community college experience. In T. Bailey \& V. M. Smith (Eds.), Defending the community college equity agenda.

Ehrmann, S. C. (1999). Access and/or quality? Redefining choices in the third revolution. The Teaching, Learning, and Technology Group, Inc. Retrieved June 15, 2001, from http://www.tltgroup.org/ resources/or\%20quality.htm

Eliade, M. (1963). Myth and reality (Trans. W. R. Trask). New York: Harper and Row.

Garfinkel, H. (1967). Studies in ethnomethodology. Englewood Cliffs, NJ: Prentice-Hall.

Garofoli, E., \& Woodell, J. (2003, January 1). Faculty development and the diffusion of innovations. Syllabus: Technology for Higher Education. Retrieved January 20, 2003, from http:// www.syllabus.com/article.asp?id $=7093$

Goodrick, E., \& Salancik, G. R. (1996, March). Organizational discretion in responding to institutional practices: Hospitals and Cesarean births. Administrative Science Quarterly, 41, $1-28$.

Grose, T. K. (1999, November). Distance education the UK way: Great Britain's decades-old Open University gets particularly high marks for its engineering courses. ASEE Prism Online: Exploring the Future of Engineering Education. Retrieved from http://www.asee.org/prism/ nov99/html/distance.htm

Grubb, W. N. (1996). Learning to work: The case for reintegrating job training and education. New York: Russell Sage Foundation.

Grubb, W. N., \& Associates. (1999). Honored but invisible: An inside look at teaching in community colleges. New York: Routledge.

Jepperson, R. L., \& Meyer, J. W. (1991). The public order and the construction of formal organizations. In W. W. Powell \& P. J. DiMaggio (Eds.), The new institutionalism in organizational analysis (pp. 204-231). Chicago: University of Chicago Press.

Katz, M. C. (1982). Critical literacy: A conception of education as a moral right and a social ideal. In R. Everhart (Ed.), The public school monopoly (pp. 193-223). Cambridge, MA: Ballinger. 
Labaree, D. (1997). Private goods, public goods: The American struggle over educational goals. American Educational Research Journal, 34(1), 39-81.

League for Innovation in the Community College. (2004). Learning College Project primer. Retrieved from http://www.league.org/league/projects/lcp/primer.htm

Meyer, J. W., \& Rowan, B. (1977). Institutionalized organizations: Formal structure as myth and ceremony. American Journal of Sociology, 83(2), 340-363.

Meyer, K. A. (2002). Quality in distance education: Focus on on-line learning (ASHE-ERIC Higher Education Report, Volume 29, No. 4. San Francisco: Jossey-Bass.

Miles, M. B., \& A. M. Huberman. (1994). Qualitative data analysis: An expanded sourcebook (2nd ed.). Thousand Oaks CA: Sage.

National Center for Education Statistics. (2002). Teaching with technology: Use of telecommunications technology by postsecondary instructional faculty and staff in fall 1998 (NCES 2002-161). Washington, DC: Author.

Newman, F. (2000, September/October). Saving higher education's soul. Change, 32(5), 16-23.

Noble, D. (1998). Digital diploma mills: The automation of higher education. First Monday, 3(1), Retrieved from http://www.firstmonday.org/issues/issue3_1/index.html

Palattella, J. (2001). May the course be with you. Lingua Franca: The Review of Academic Life, $11(2), 50-57$.

Richardson, R. C., Fisk, E., \& Okun, M. (1983). Literacy in the open-access college. San Francisco: Jossey-Bass.

Rogers, E. M. (1962). Diffusion of innovations. New York: Free Press of Glencoe.

Scott, W. R. (1991). Unpacking institutional arguments. In W. W. Powell \& P. J. DiMaggio (Eds.), The new institutionalism in organizational analysis (pp. 164-182). Chicago: University of Chicago Press.

Selfe, C. L. (1999). Technology and literacy in the twenty-first century: The importance of paying attention. Carbondale: Southern Illinois University Press.

Spann, M. G., Jr. (2000). Remediation: A must for the 21st century learning society (Policy Paper). Denver, CO: Education Commission of the States.

Trow, M. (2000). Some consequences of the new information and communication technologies for higher education (Policy Paper Series 5.00). Berkeley: University of California, Center for Studies in Higher Education. Working draft retrieved from http://ishi.lib.berkeley.edu/cshe/.

Twigg, C. A. (2002). The impact of the changing economy on four-year institutions of higher education: The importance of the Internet. In P. A. Gram \& N. Stacey (Eds.), The knowledge economy and postsecondary education: Report of a workshop (pp. 77-104). Washington, DC: National Academy Press.

Weick, K. E. (1969). The social psychology of organizing. Reading, MA: Addison-Wesley.

Weick, K. E. (2001). Enactment processes in organizations. In Making sense of the organization (pp. 179-206). Malden, MA: Blackwell.

Yin, R. K. (1989). Case study research: Design and methods. Beverly Hills, CA: Sage.

Zucker, L. G. (1987). Institutional theories of organizations. Annual Review of Sociology, 13, 443-464.

REBECCA D. COX is a research associate at the Community Collage Research Center at Teachers College. Her research interests center on issues of equity and access in higher education and include investigation of the organizational and institutional contexts of faculty work and the realities of teaching and learning inside community college classrooms. 